\title{
Pelatihan Prosedur Penanganan Dan Mitigasi Penyebaran Kasus Covid-19
}

\author{
Dedi Rianto Rahadi ${ }^{1}$, Rusdianto ${ }^{2}$, Hadi Suprayitno ${ }^{3}$ \\ Universitas Presiden, Cikarang, Jawa Barat ${ }^{1,2,3}$ \\ Email:dedi1968@president.ac.id
}

\begin{abstract}
ABSTRAK
Berdasarkan Journal of the American Medical Assosiation, para peneliti menemukan bahwa banyaknya orang yang terjangkit Covid-19 hanya mengalami gejala ringan dan tidak sampai meninggal. Corona Virus disebabkan oleh virus Sars-CoV-2, gejala yang ditimbulkan dapat disertai dengan Flu, batuk, demam, sesak, anosmia, lemas, nyeri otot dan juga diare. Tujuan adanya pengabdian masyarakat ini adalah untuk mengetahui seberapa bahayanya virus corona dan bagaimana cara mengatasi diri di perkantoran agar tidak tertular. Metode penelitian ini menggunakan metode kualitatif dan juga metode survei. Metode kualitatif bertujuan untuk penulis mengetahui fakta fakta yang terjadi dilapangan dan metode survei dilakukan untuk mengetahui seberapa banyak orang yang mengetahui permasalahan ini. Berdasarkan hasil penelitian mengenai berapa lama virus tersebut hidup pada sebuah benda atau permukaan. Pada baja, virus dapat bertahan selama 4 jam. Pada alumunium, virus dapat bertahan selama 2 hingga 8 jam. Pada logam, virus dapat bertahan hingga 5 hari. Hal ini dapat diketahui bahwa rentannya tertular virus hanya dengan menyentuh benda seperti yang telah disebutkan. Tidak hanya melalui benda atau permukaan, virus corona juga dapat menyebar dan bisa tertular melalui cairan berupa batuk, bersin dan berjabat tangan.
\end{abstract}

Kata kunci : Penularan, siklus hidup virus, gejala yang ditimbulkan

\begin{abstract}
According to the Journal of the American Medical Association, researchers found that many people who contract Covid-19 experience only mild symptoms and do not die. Corona Virus is caused by the Sars-CoV-2 virus, the symptoms caused can be accompanied by flu, cough, fever, spasms, anosmia, weakness, muscle aches and also diarrhea. The purpose of this community service is to find out how dangerous the corona virus is and how to deal with yourself in offices so you don't get infected. This research method uses qualitative methods as well as survey methods. The qualitative method aims for the author to know the facts that occur in the field and the survey method is carried out to find out how many people know about this problem. Based on the results of research on how long the virus lives on an object or surface. In steel, the virus can last for 4 hours. On aluminum, the virus can last for 2 to 8 hours. On metals, the virus can last up to 5 days. It can be seen that the susceptibility of contracting the virus only by touching objects as mentioned. Not only through objects or surfaces, the corona virus can also spread and can be transmitted through fluids in the form of coughing, sneezing and shaking hands.
\end{abstract}

Keyword: Transmission, the life cycle of the virus, the symptoms it causes. 


\section{PENDAHULUAN}

Menurut Kemenkes RI, 2020 Virus Corona disebabkan oleh Virus Sars-CoV-2. Gejala yang ditimbulkan berupa Flu, batuk, demam, sesak, anosmia, lemas, nyeri otot, dan juga diare. Penderita COVID-19 yang berat dapat menimbulkan Pneumonia, Syndrome pernafasan akut, gagal ginjal bahkan hingga kematian.

Virus Corona ini merupakan virus yang menyerang pernafasan manusia. Gejala corona ini dapat dideteksi setalah 2-14 hari setelah ciri ciri seperti yang telah dijelaskan terjadi. Berdasarkan Journal of the American Medical Assosiation para peneliti menemukan banyaknya orang yang hanya mengalami gejala ringan dan tidak menimbulkan kematian. Gejala yang paling umum yaitu demam, batuk kering, kelelahan dan merasa tidak enak badan. Dan gejala lainnya seperti pusing, nyeri kepala dan juga sakit perut dan diare. Penularan dari manusia ke manusia dapat melalui cairan seperti batuk, bersin dan berjabat tangan. Virus akan menular jika anda menyentuh cairan orang yang terinfeksi lalu menyentuh mata, hidung serta mulut.

Berdasarkan data yang didapatkan dari website resmi pemerintah, terhitung sejak tanggal 2 maret 2020, beberapa kali grafik kasus konfirmasi positif COVID-19 menunjukkan peningkatan yang signifikan seperti pada bulan Mei 2020, Juli 2020 dan Januari 2021. Maksud dan tujuan penelitian pengabdian masyarakat ini adalah untuk memberikan pengetahuan kepada masyarakat yang menyadari adanya COVID-19 dan bahayanya serta menginformasikan bagaimana cara menghindari terjadinya penularan virus COVID-19.

\section{METODE}

Di masa Covid-19 ini masih banyak pasien yang terjangkit virus tersebut karena kurangnya kesadaran kepada diri sendiri akan bahaya virus ini seperti tidak menggunakan masker dengan benar di lingkungan luar, berkerumunan dengan orang banyak. Sehubungan masih adanya virus covid-19 dan mencegah terjadinya penularan, maka pengabdian masyarakat dilakuakna secara webinar. Pengabdian masyarakat ini melibatkan dosen dan mahasiswa dengan metode pendekatan interatif antara pembicara dengan masyarakat. Diawali dengan pembuatan poster sebagai media untuk menginformasikan kegiatan pengabdian masyarakat. 


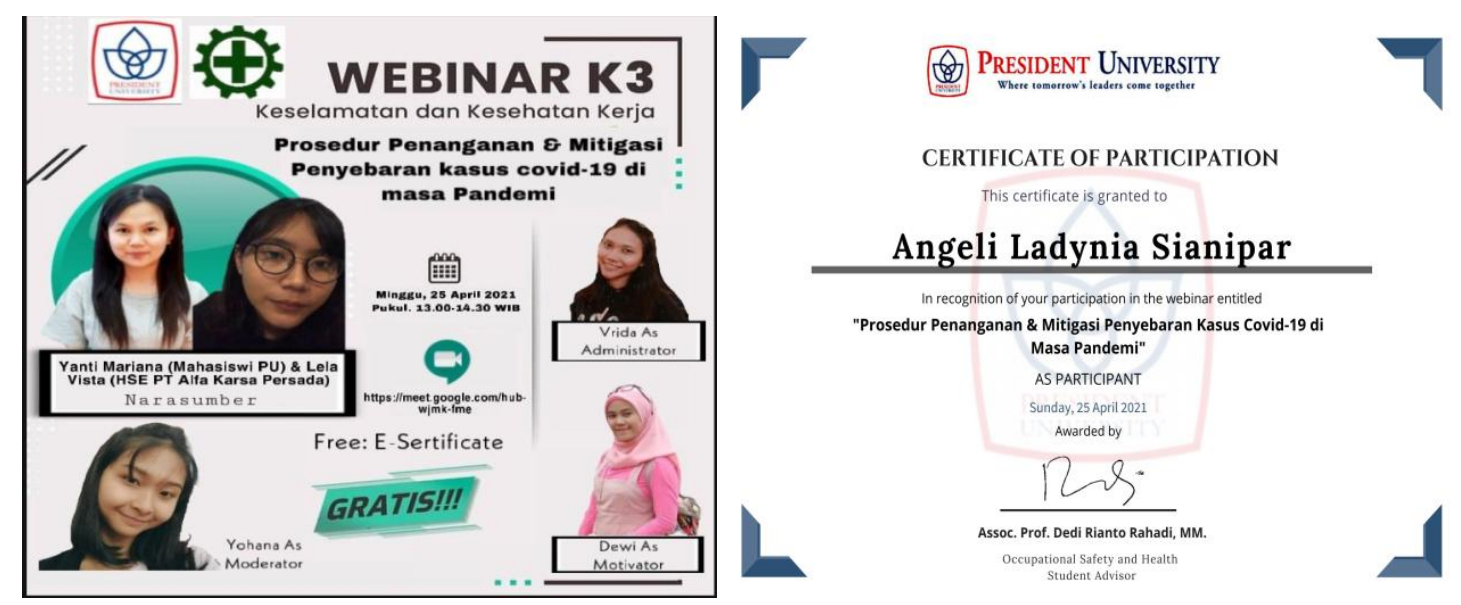

Gambar 1. Contoh Poster dan Sertifikat Kegiatan

Kemudian webinar ini juga memberikan pelatihan secara virtual bagai mana caranya agar terhindar dari virus Covid-19 ini, seperti bagaimana bersosialisasi dengan rekan kerja, Bagaimana melakukan penanganan dan mitigasi menghadapi covid-19.

\section{HASIL, PEMBAHASAN, DAN DAMPAK}

Webinar tentang Pelatihan Prosedur Penanganan dan Mitigasi Penyebaran Kasus COVID-19 yang dilaksanakan pada hari Minggu, tanggal 25 April 2021, dikuti 40 peserta, khususnya dilingkungan kawasan industry Jababeka, Cikarang melalui kegiatan webinar.
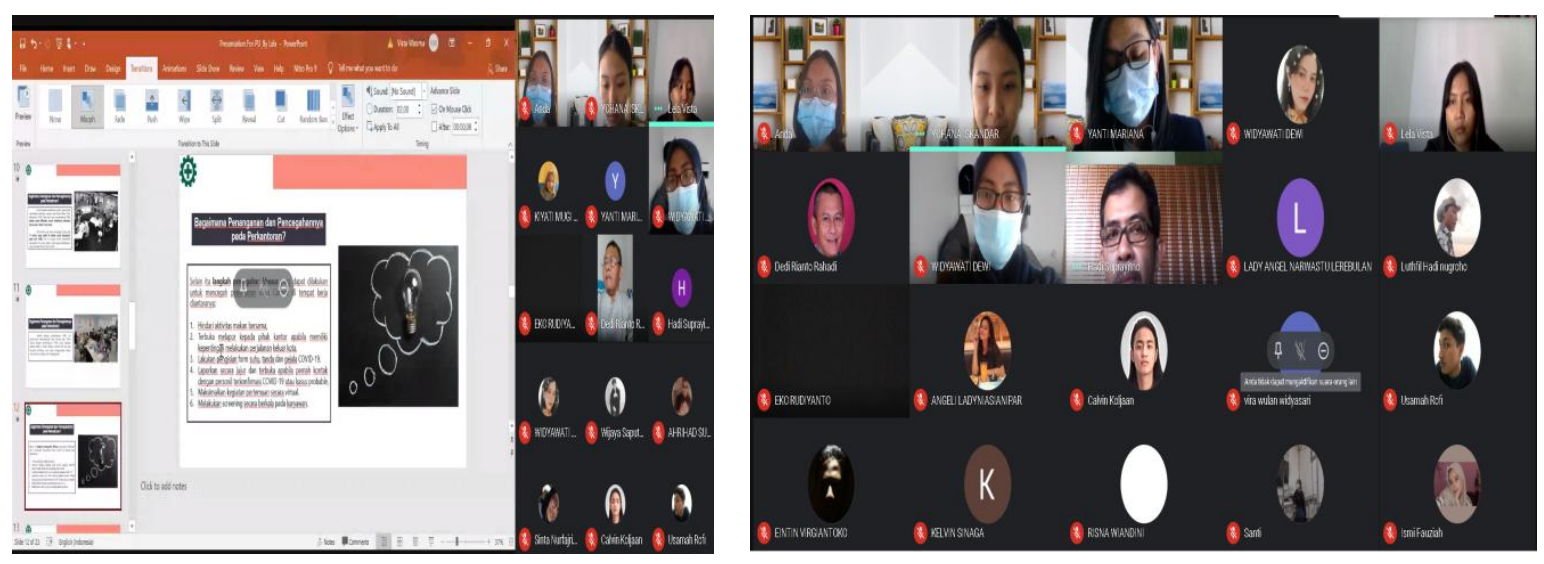

Gambar 2. Kegiatan Webinar

Virus corona merupakan virus yang menyerang pada sistem pernafasan manusia, menyebabkan gangguan ringan pada sistem pernafasan manusia, infeksi paru-paru yang berat hingga kematian dan gejala tersebut akan timbul setelah 2-14 hari. Ada beberapa pertanyaan yang diajukan pada saat webinar, diantaranya : 
Tabel 1. Daftar Pertanyaan Peserta Webinar

\begin{tabular}{|l|l|}
\hline \multicolumn{1}{|c|}{ Pertanyaan } & \multicolumn{1}{|c|}{ Jawaban } \\
\hline $\begin{array}{l}\text { Apakah virus corona dapat } \\
\text { menyebar melalui udara yg } \\
\text { sirkulasi nya tidak baik? } \\
\text { (Tertutup) }\end{array}$ & $\begin{array}{l}\text { Dapat, karena jika kita berada di dalam ruangan tertutup } \\
\text { sersama orang yang terinfeksi virus corona dan tidak ada } \\
\text { sirkulasi udara maka terdapat kemungkinan yang sangat }\end{array}$ \\
\hline $\begin{array}{l}\text { Apa tindakan yang harus } \\
\text { dilakukan oleh pemerintah } \\
\text { untuk mencegah adanya } \\
\text { virus jenis baru masuk } \\
\text { kedalam indonesia? }\end{array}$ & $\begin{array}{l}\text { Menutup akses masuknya orang asing, jika tidak dapat di } \\
\text { eksekusi setidak lebih ketat dalam pemeriksaan terhadap } \\
\text { di wajibkan melakukan swab test dan dilakukan isolasi } \\
\text { selama 14 hari agar memastikan orang yang masuk } \\
\text { kedalam negara indonesia dalam kondisi sehat tidak } \\
\text { terinfeksi virus corona }\end{array}$ \\
\hline $\begin{array}{l}\text { Apakah vaksin kedepannya } \\
\text { akan disediakan untuk anak } \\
\text { kecil? }\end{array}$ & $\begin{array}{l}\text { Dalam pemberitaan Kompas.com, para peneliti akan } \\
\text { menggunakan 300 sukarelawan anak untuk menguji } \\
\text { keefektifan vaksin Oxford/AstraZeneca Covid-19 pada } \\
\text { anak-anak berusia antara 6 hingga 17 tahun. }\end{array}$ \\
\hline $\begin{array}{l}\text { Mengapa sudah di vaksin } \\
\text { corona? tetap terpapar virus }\end{array}$ & $\begin{array}{l}\text { Ada kemungkinannya sebelum dilakukan proses vaksin, } \\
\text { orang tersebut sudah terinfeksi virus corona, jadi } \\
\text { membutuhkan vaksin kedua kali nya }\end{array}$ \\
\hline
\end{tabular}

\section{PEMBAHASAN}

Penanganan Covid-19 tidak hanya peran dari pemerintah tetapi juga harus didukung dan melibatkan semua lapisan masyarakat agar kegiatan ini bisa berjalan secara efektif. Covid -19 bisa muncul dimana saja, baik di cluster rumah tangga, perkatoran, mall dan sebagainya, hal ini menjadi focus kepada kita semua, bahwa covid bisa muncul dimana saja.

Kondisi ini perlu menjadi perhatian setiap masyarakat, berdasarkan hasil penelitian yang diterbitkan dalam The Journal of Hospital Infection, mengenai berapa lamakah virus tersebut dapat bertahan hidup pada sebuah benda dan atau permukaan, seperti terlihat pada gambar 2 . 


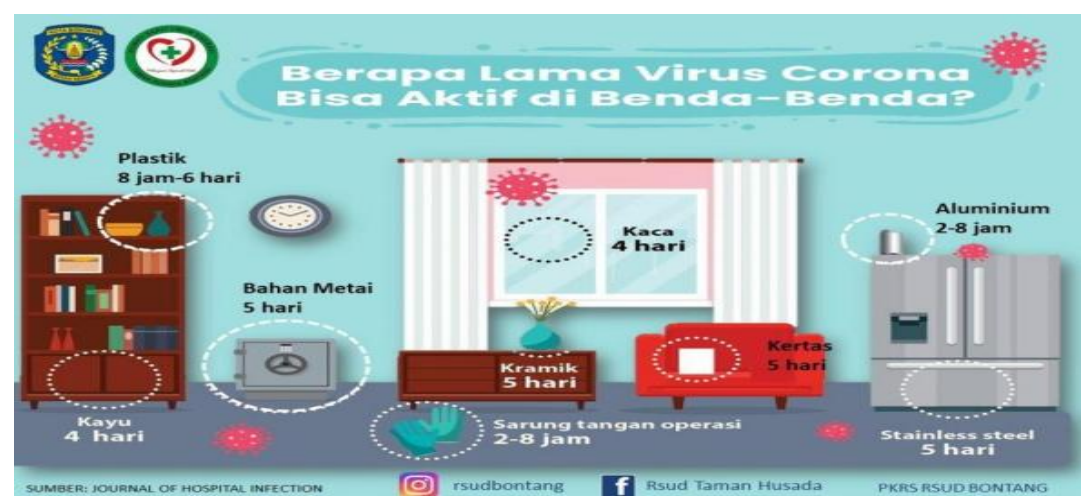

Gambar 3. Kehidupan Virus Corona

Setiap masyarakat, khususnya pegawai yang bekerja diperkantoran maupun pabrik harus memahami dan mengenal gejala-gejala virus corona serta tindakan pencegahannya. Hal ini tidak hanya menjadi tanggung jawab perusahaan tetapi juga semua pegawai agar semuanya terhindar dari covid-19. Pada gambar 4, diperlihatkan bagaimana cara mencegah dan mengenali covid-19 agar semua pegawai paham dan mampu untuk menghindarinya.

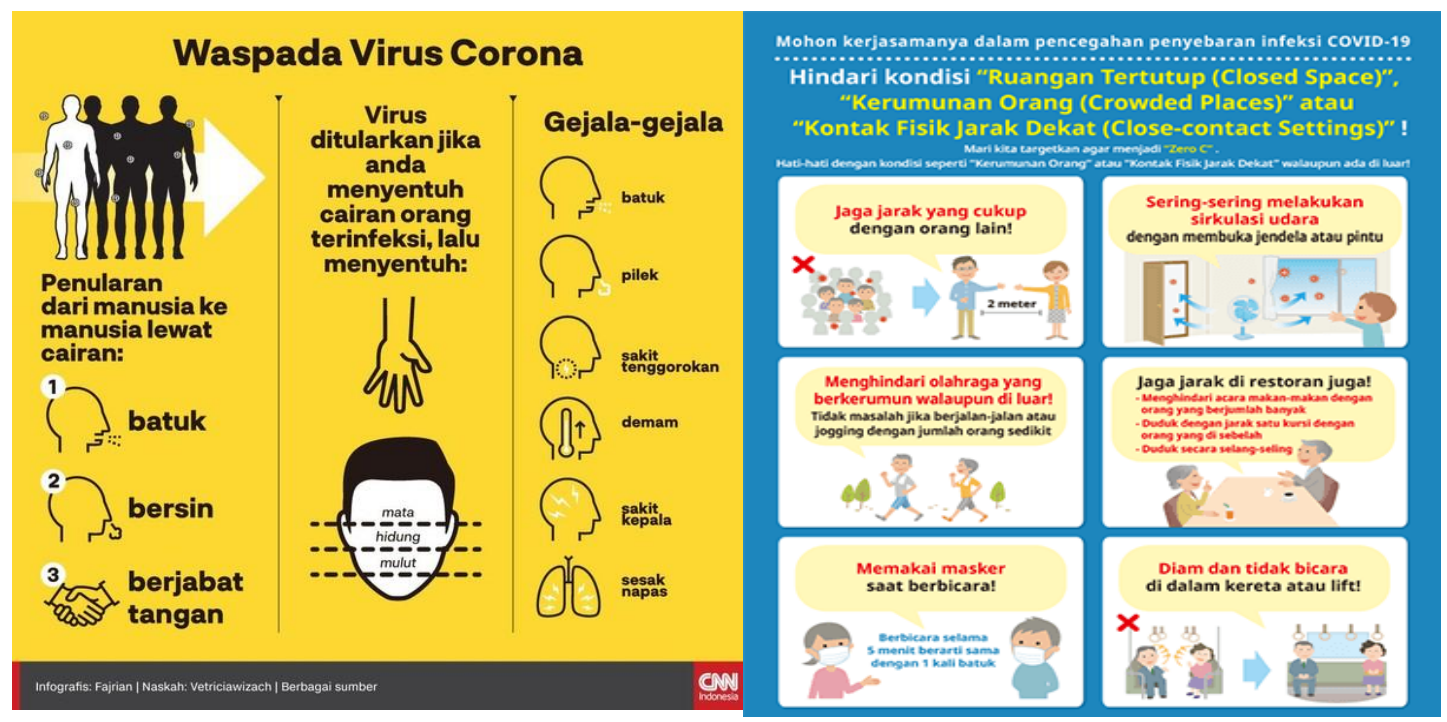

Gambar 4 Pengenalan dan Pencegahan Covid-19.

Dengan disiplin yang tinggi serta dibarengi dengan pengetahuan serta pencegahan, diharapkan covid tidak menimbulkan cluster baru diperkantoran dan keluarga, sehingga semua akan terbebas dari covid-19. 


\section{SIMPULAN}

Berdasarkan hasil penelitian diatas dapat disimpulkan bahwa virus corona dapat menyerang siapapun dan dimanapun. Gejala yang ditimbulkan yaitu batuk, pilek, sakit tenggorokan, sesak napas, demam dan sakit kepala. Virus corona dapat menular melalui batuk, bersentuhan atau berjabat tangan, bersin, dan menyentuh permukaan atau benda yang terdapat virus. Agar terhindar dari virus corona maka harus menjaga imunitas tubuh, kini kemenkes sudah mengeluarkan vaksin untuk membentuk sistem kekebalan tubuh. Manfaat dari vaksinasi ini yaitu untuk menurunkan angka kesakitan atau kematian akibat covid-19 dan mendorong terbentuknya herd immunity. Kini pemerintah juga menganjurkan untuk melakukan 5M agar terhindar dari virus corona yaitu memakai masker, mencuci tangan pakai sabun dan air yang mengalir, menjaga jarak, menjauhhi kerumunan, serta membatasi mobilisasi dan interaksi.

Untuk penelitian selanjutnya, diharapkan dapat mencari data-data terbaru dan fakta terbaru yang valid tentang covid-19 agar masyarakat dapat mengantisipasi untuk mencegah terjadinya penularan virus corona.

\section{DAFTAR PUSTAKA}

ABC Australia. (2020, Mar). Siapa Saja yang Lebih Rentan Terjangkit Virus Corona?. Diunduh dari https://news.detik.com/abc-australia/d-4922923/siapa-saja-yang-lebihrentan-terjangkit-virus-corona.

Barratut Taqiyyah. (2021, Jan). Sudah divaksin tetapi bisa positif Covid-19? Ini penjelasannya. Diunduh dari https://kesehatan.kontan.co.id/news/sudah-divaksintetapi-bisa-positif-covid-19-ini-penjelasannya?page=all

Bernadette Aderi Puspaningrum. (2021, Feb). Pertama di Dunia, Vaksin Covid-19 AstraZeneca Akan Diuji pada Anak 6 Tahun. Diunduh dari https://www.kompas.com/global/read/2021/02/13/205005070/pertama-di-duniavaksin-covid-19-astrazeneca-akan-diuji-pada-anak-6-tahun?page=all .

CNN Indonesia. (2020, Feb). 9 Pertanyaan yang Sering Muncul tentang Virus Corona. Diunduh dari https://www.cnnindonesia.com/gaya-hidup/20200207144129-255472609/9-pertanyaan-yang-sering-muncul-tentang-virus-corona.

Kemenkes. (2020). COVID-19. Diunduh dari https://www.alodokter.com/covid-19.

Kemenkes. (2021). Virus Corona. Diunduh dari https://www.alodokter.com/virus-corona.

Kiswondari. (2021, Apr). Eksodus WN India ke Indonesia, Pemerintah Harus Ambil Tindakan Tegas.

Diunduh dari 
https://nasional.sindonews.com/read/406348/12/eksodus-wn-india-ke-indonesiapemerintah-harus-ambil-tindakan-tegas-1619157898.

Poster untuk penanggulangan penyebaran virus Corona tipe baru. Diunduh dari https://corona.go.jp/id/.

Rina Rahmawati. (2020, Mar). Berapa Lama Virus Corona Bertahan pada Permukaan Benda?. Diunduh dari https://www.sehatq.com/artikel/berapa-lama-virus-coronabertahan-pada-permukaan-benda.

Rodrigo Arangua. (2020, Jul). Virus corona: Bisa menyebar lewat udara, penularan Covid19 di ruangan tertutup kian berisiko. Diunduh dari https://www.bbc.com/indonesia/majalah-53344413. 